\title{
Jurassic dinocysts from the Warboys Borehole, Cambridgeshire, England
}

\author{
J. B. RIDING \\ Institute of Geological Sciences, Ring Road, Halton, Leeds LS15 8TQ, England
}

\begin{abstract}
The stratigraphic distribution of dinocysts in sediments of Toarcian to carly Oxfordian age from the Warboys Borehole, Cambridgeshire are described. Several forms have relatively restricted ranges and appear to be of stratigraphic value. Selected forms are illustrated.
\end{abstract}

\section{INTRODUCTION}

The IGS Warboys Borehole, Broughton, Cambridgeshire (TL 2903 7839) was drilled in early 1965 (Fig. 1) as part of an investigation into geophysical anomolies in the western Fens, and proved the following sequence:

$$
\begin{array}{cc}
\text { Thickness } & \text { Depth } \\
\text { (metres) } & \text { (metres) }
\end{array}
$$

\section{Pleistocene:}

Drift Deposits

$$
1.295
$$

Jurassic:

Oxford Clay

Kellaways Beds

63.272

5.511

64.567

Cornbrash

Blisworth Limestone

1.220

70.078

3.886

71.298

1.436

75.184

Upper Estuarine 'Series'

76.620

Grantham Formation

10.527

87.147

Upper Lias

8.967

96.114

Middle and Lower Lias

74.345

170.459

Pre Jurassic:

Diorite (age uncertain)

$46.711 \quad 217.459$

Bottom of Hole

An excellent account of the sediments studied is given in Chapters 11 to 14 of Sylvester-Bradley \& Ford (1968). The strata accumulated in the 'Oxfordshire shallows', (a swell region, close to the western edge of the London landmass), in a shallow water, mainly marine sedimentary régime.

The ammonite zonation used in this account is the work of Callomon (unpublished data, 1966) who proved a complete Callovian zonal sequence; those zones sampled for this study are shown in Fig. 2. The zonal sequence from the Toarcian to the Bathonian is incomplete and may be explained by both non-deposition and erosion.

This study is part of a project aiming at a refined zonation of the British Jurassic using dinocysts. The asscmblage slides and figured material is housed in the MPA and MPK collections respectively, of the Institute of Geological Science, Leeds.

\section{PALYNOLOGICAL ANALYSIS}

Twenty-six samples were prepared for palynological study (Table 1). The residues were found to be dominated by miospores, plant cuticle and wood débris. This dominance of land plant derived material strongly suggests that the sediments accumulated in a relatively nearshore environment.

Rich, well-preserved dinocyst assemblages were encountered in all but two of the samples. Many of the taxa recognised have relatively long ranges although several with more restricted ranges appear to be stratigraphically useful.

\section{STRATIGRAPHIC DISTRIBUTION OF DINOCYSTS}

The distribution of the dinocyst taxa is outlined in Fig. 2.

TOARCIAN/AALENIAN $(87.325-79.248 \mathrm{~m}$.$) -$ This interval is characterised by a low dinocyst diversity. Nannoceratopsis gracilis Alberti, 1961 is abundant at the Toarcian/Aalenian boundary, but has a total range of Pleinsbachian to Bathonian (Thusu, 1978). Nannoceratopsis ambonis Drugg, 1978 is very characteristic of the Aalenian in Britain; it has never been encountered in the Lias.

Two samples taken from the Grantham Formation (at $79.248 \mathrm{~m}$. and $82.296 \mathrm{~m}$.) proved to be barren of marine palynomorphs (dinocysts, acritarchs and tasmanitids). The palynomorphs are entirely terrestrially derived, indicating that the sediment accumulated in a nonmarine environment.

BATHONIAN/EARLY CALLOVIAN (76.200$70.104 \mathrm{~m}$.) - A number of taxa make their first appearance in the Upper Estuarine 'Series' (76.200m.). Several of these taxa have been recorded from the late Bajocian, which is not represented in this section. These include, Valensiella ovula (Deflandre, 1947) Eisenack, 


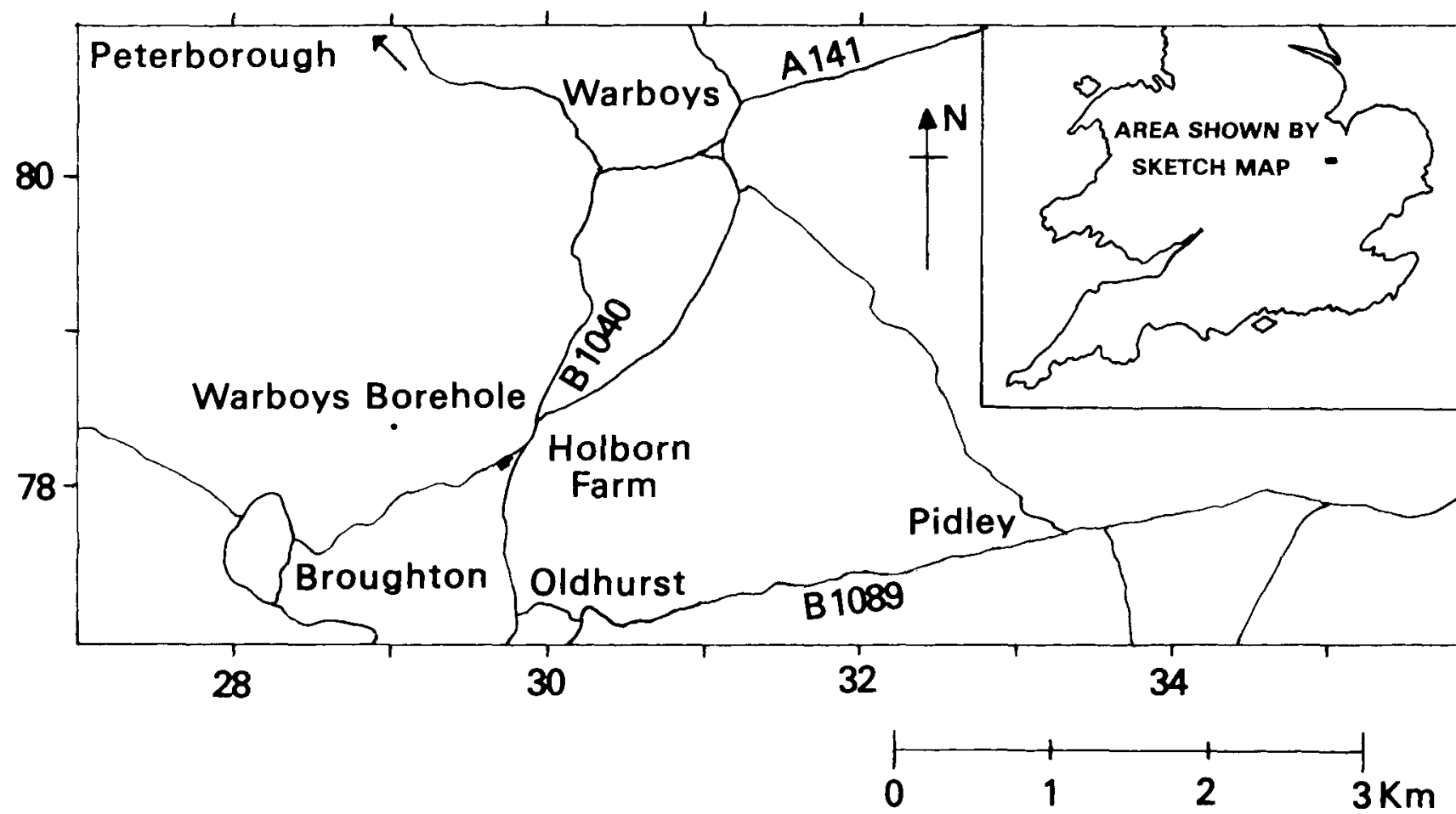

Fig. 1. Location of Warboys Borehole.

1963, Tubotuberella eisenackii (Deflandre, 1938) Stover \& Evitt, 1978 and Ctenidodinium sellwoodii (Sarjeant, 1975) Stover \& Evitt, 1978.

Several taxa appear in the Cornbrash $(70.104 \mathrm{~m})$; many of these have been reported from the Bathonian (Thusu, 1978; Sarjeant, 1978). These include Adnatosphaeridium aemulum (Deflandre, 1938) Williams \& Downie, 1969, Adnatosphaeridium caulleryi (De- flandre, 1938) Williams \&. Downie, 1969, Hystrichogonyaulax pectinigera (Gocht, 1970) Stover \&. Evitt, 1978, Kalyptea stegasta (Sarjeant, 1961) Wiggins, 1975, Mendicodinium groenlandicum (Pocock \& Sarjeant, 1972) Davey, 1979b, Nannoceratopsis pellucida Deflandre, 1938 and Sentusidinium rioultii (Sarjeant, 1968) Sarjeant \& Stover, 1978.

\section{Explanation of Plate 1}

All specimens are x 700. "England Finder" co-ordinates follow the slide number for each specimen.

Fig. 1. Scriniodinium crystallinum (Deflandre, 1938) Klement, 1960: MPK 3557, MPA $12053 / 2$, C54.

Fig. 2. Endoscrinium sp. Muir \& Sarjeant, 1978: MPK 3558, MPA 12059/2, P32/2.

Fig. 3. Chytroeisphaeridia cerastes Davey, 1979a: MPK 3559, MPA 12063/2, Q57.

Fig. 4. Belodinium asaphum Drugg, 1978: MPK 3560, MPA 12054/2, J57/3.

Fig. 5. Mendicodinium groenlandicum (Pocock \& Sarjeant, 1972) Davey, 1979b: MPK 3561, MPA 12064/2, J59.

Fig. 6. Hapsidaulax margarethae Sarjeant, 1975: MPK 3562, MPA 12071/1, T59/4.

Fig. 7. Reutlingia gochtii Drugg, 1978: MPK 3563, MPA 12059/2, H39/3.

Fig. 8. Stephanelytron scarburghense Sarjeant, 1961 emend. Stover et al., 1977: MPK 3564, MPA 12056/2, Q28/2.

Fig. 9. Stephanelytron redcliffense Sarjeant, 1961 emend. Stover et al., 1977: MPK 3565, MPA 12059/1, B31/1.

Fig. 10. Dinopterygium absidatum Drugg, 1978: MPK 3566, MPA 12056/2, K37/3.

Fig. 11. Adnatosphaeridium aemulum (Deflandre, 1938) Williams \& Downie, 1969: MPK 3567, MPA 12058/2, $\mathrm{S} 29 / 3$. 

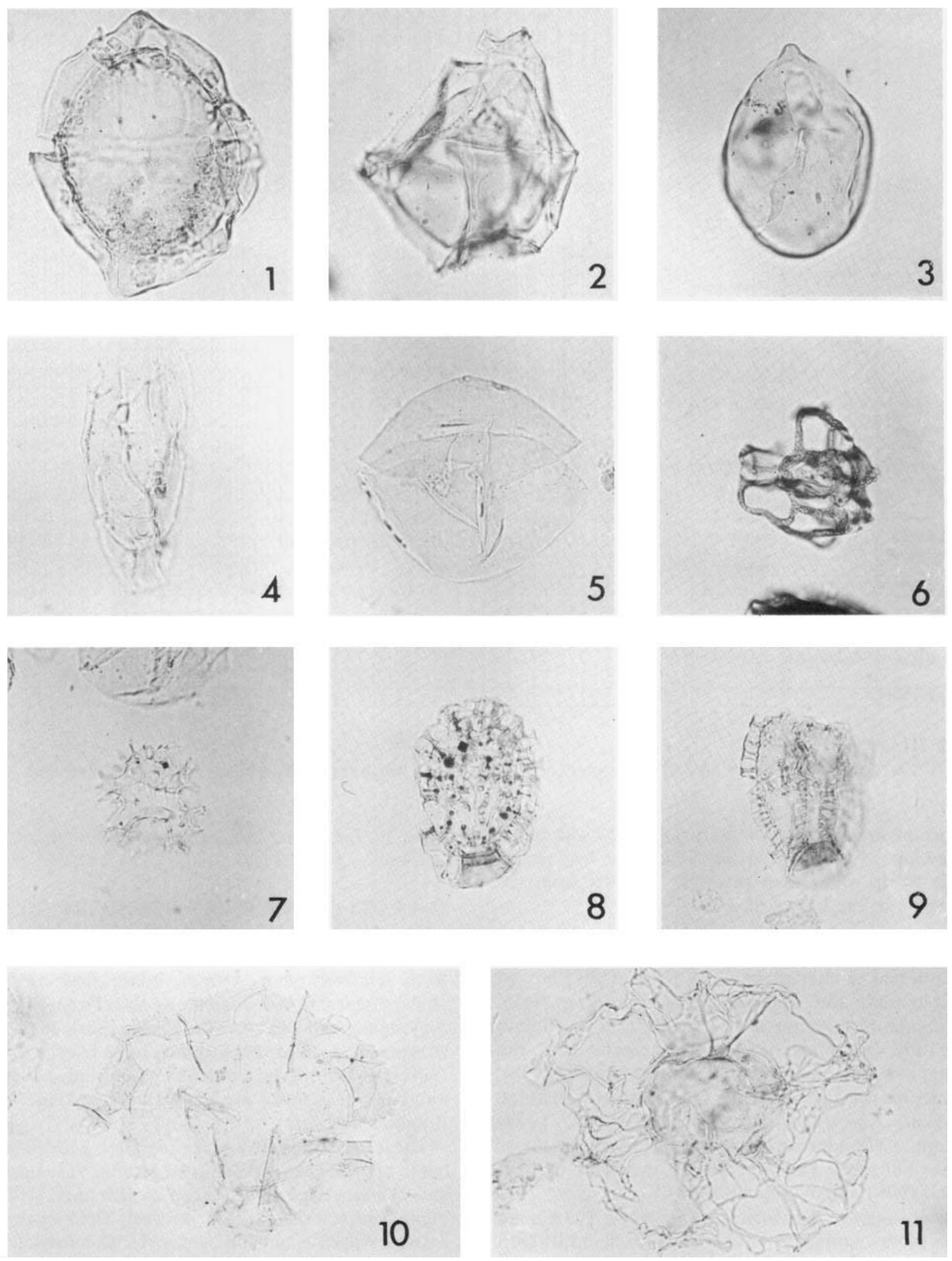

11 


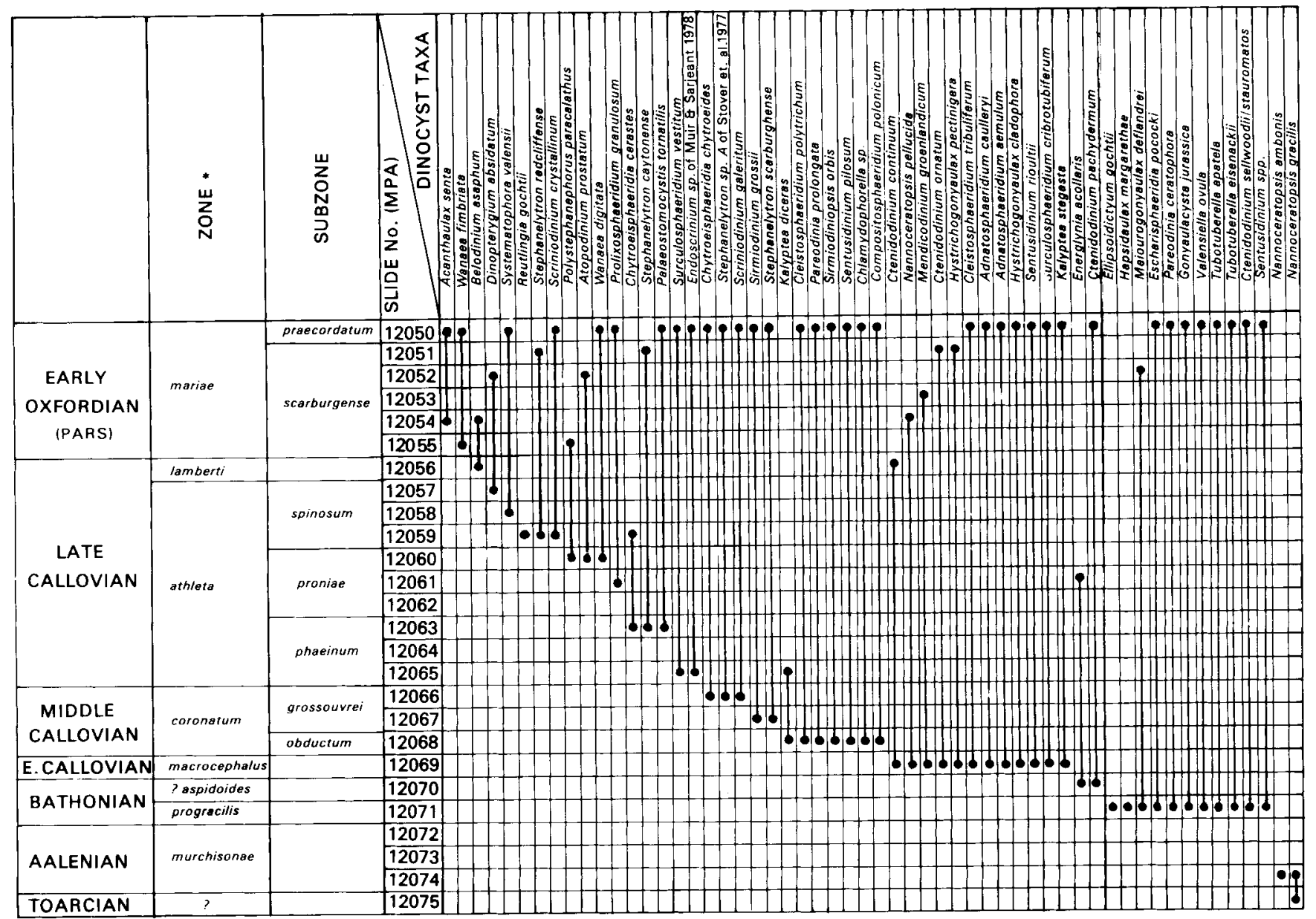

Fig. 2 Dinocyst range chart.

*A complete Callovian zenal sequence was proved, however, only those zones sampled are shown.

Hapsidaulax margarethae Sarjeant, 1975 was found in the Upper Estuarine 'Series'. This is the first record of this form, other than the type material from the Bathonian of the Isle of Skye.

MIDDLE/LATE CALLOVIAN (62.484-24.384m.) This interval is characterised by a great diversity of dinocysts and the appearance of significant taxa. Ctenidodinium continuum Gocht, 1970 is not found above the late Callovian, which accords with the findings of Woollam (1980), but not with Thusu (1978), who records this form from the Oxfordian as well as the Callovian. Energlynia acollaris (Dodekova, 1974) Sarjeant, 1978 appears to die out in the athleta Zone, proniae Subzone. This agrees with the work of both Thusu (1978) and Woollam (1980).

The presence of Reutlingia gochtii Drugg, 1978 in the athleta Zone, spinosum Subzone, (33.528-35.052m.) constitutes its first published record other than the type material (it was originally described from the athleta zone in Germany and appears to be an excellent marker).

CALLOVIAN/OXFORDIAN BOUNDARY (23.799 m.) - Atopodinium prostatum Drugg, 1978 and Dinopterygium absidatum Drugg, 1978 span this boundary and have relatively short ranges, hence they are useful stratigraphically. Belodinium asaphum Drugg, 1978 and Polystephanephorus paracalathus (Sarjeant, 1960) Downie \& Sarjeant, 1965 appear to be restricted to the Callovian/Oxfordian boundary according to Fig. 2, although these forms are known to have longer ranges (unpublished data).

The aforementioned taxa, together with Stephanelytron spp., Endoscrinium sp. of Muir \& Sarjeant, 1978 and Wanaea digitata Cookson \& Eisenack, 1958 are highly characteristic of this interval. Their distribution in the Warboys section is generally consistent with Raynaud (1978), Thusu (1978) and Woollam (1980). 
Table 1. Details of Samples

$\begin{array}{cr}\text { Slide Number } & \text { Depth (metres) } \\ \text { MPA } 12050 & 5.181-6.096 \\ 12051 & 9.144-10.668 \\ 12052 & 12.192-13.716 \\ 12053 & 15.240-16.764 \\ 12054 & 18.288-18.313 \\ 12055 & 21.336-22.860 \\ 12056 & 24.384-24.409 \\ 12057 & 27.432-28.956 \\ 12058 & 30.480-30.505 \\ 12059 & 33.528-35.052 \\ 12060 & 36.576-38.100 \\ 12061 & 39.624-41.148 \\ 12062 & 42.672-44.196 \\ 12063 & 45.720-47.244 \\ 12064 & 48.768-50.292 \\ & \\ 12065 & 51.816-53.340 \\ 12066 & 54.864-56.388 \\ 12067 & 57.912-59.436 \\ 12068 & 60.960-62.484 \\ 12069 & 70.104 \\ 12070 & 73.152 \\ 12071 & 76.200 \\ 12072 & 79.248 \\ 12073 & 82.296 \\ 12074 & 85.344 \\ 12075 & 87.325\end{array}$

Lithostratigraphic Unit

Upper Oxford Clay

, , ,

, , , ,

, , , ,

, , , ,

, , , ,

Middle Oxford Clay

," , ,

, , , ,

, , , ,

, , , ,

, , , ,

, , , ,

", , ",

Middle Oxford Clay - to $49.225 \mathrm{~m}$

Lower Oxford Clay - to $50.292 \mathrm{~m}$

Lower Oxford Clay

$\begin{array}{lll}, & , & , \\ ,, & , & ,\end{array}$

Cornbrash

Blisworth Limestone

Upper Estuarine 'Series'

Grantham Formation

Upper Lias
EARLY OXFORDIAN (22.860-5.181 m.) - Two taxa are confined to the early Oxfordian; Acanthaulax senta Drugg, 1978 and Wanaea fimbriata Sarjeant, 1961. A. senta is known to occur in the lamberti Zone, uppermost Callovian in Britain (unpublished data), whereas $W$. fimbriata is confined to the early Oxfordian mariae and cordatum zones in N.W. Europe, (Sarjeant, 1961; Raynaud, 1978; Thusu, 1978; Woollam, 1980).

\section{ACKNOWLEDGEMENTS}

This paper is published by kind permission of the Director, Institute of Geological Sciences, London (N.E.R.C.).

\section{REFERENCES}

(References to the taxa recognised may be found in Stover \& Evitt, 1978).

Davey, R.J. 1979a. A re-appraisal of the genus Chytroeisphaeridia Sarjeant 1962. Palynology, 3, 209-218.

Davey, R.J. 1979b. The stratigraphical distribution of dinocysts in the Portlandian (latest Jurassic) to Barremian (early Cretaceous) of northwest Europe. AASP Contributions Series, No. 5B, 49-81.

Drugg, W.S. 1978. Some Jurassic dinoflagellate cysts from England, France and Germany. Palaeontographica, Cassel, Abt. B, 168, 61-79.

Erkmen U. \& Sarjeant, W.A.S. 1980. Dinoflagellate cysts, acritarchs and tasmanitids from the uppermost Callovian of England and Scotland: with a reconsideration of the Xanthidium pilosum problem. Géobios, Lyon, 13, 45-99.

Fensome, R.A. 1979. Dinoflagellate cysts and acritarchs from the Middle and Upper Jurassic of Jameson Land, East Greenland. Gronlands Geologiske Undersøgelse. Bull. No. 132, 1-117. 
Muir, M.D. \& Sarjeant, W.A.S. 1978. The palynonogy of the Langdale Beds (Middle Jurassic) of Yorkshire and its stratigraphical implications. Rev. Palaeobot. Palynol., 25, 193-239.

Raynaud, J.F. 1978. Principaux dinoflagellés caractéristiques du Jurassic Supérieur d'Europe du Nord. Palinologia, núm. extraord, 1, 387-405. Sarjeant, W.A.S. 1961. Microplankton from the Kellaways Rock and Oxford Clay of Yorkshire. Palaeontology, London, 4, 90-118.

Sarjeant, W.A.S. 1975. Hapsidaulax, new genus of dinoflagellate cysts from the Jurassic (Bathonian) of the Isle of Skye. Scot. J. Geol., 11, 143-149. Sarjeant, W.A.S. 1978. A guide to the identification of Jurassic dinoflagellate cysts. Louisiana State Uni- versity, Misc. Pub. 78-1, pp. 1-107.

Stover, L.E. \& Evitt, W.R. 1978. Analyses of PrePleistocene organic-walled dinoflagellates. Stanf. Univ.Publs., 15, 1-300.

Sylvester-Bradley, P.C. \& Ford, T.D. (Eds.) 1968. The geology of the East Midlands, 1-400, Leicester University Press.

Thusu, B. (Ed.), 1978. Distribution of biostratigraphically diagnostic dinoflagellate cysts and miospores from the Northwest European Continental Shelf and adjacent areas. Continental Shelf Institute (Trondheim), Publ. No. 100, 1-109.

Woollam, R., 1980. Jurassic dinocysts from shallow marine deposits of the East Midlands, England. $J$. Univ. Sheffield Geol. Soc., 7, 243-261. 